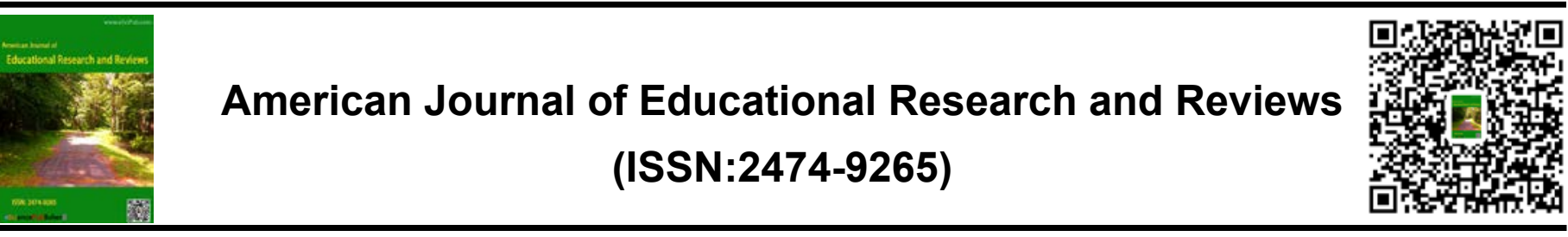

\title{
Private Estate Housing Productivity in Greater Port Harcourt, Nigeria
}

\section{Dr, (Mrs) Augusta Ayotamuno ${ }^{1}$ And Obinna Victor Chika ${ }^{2}$}

${ }^{1}$ Institute of Geosciences and Space Technology (IGST) at the Rivers State University (RSU) Nkpolu, Port Harcourt, PMB 5080, Port Harcourt, Nigeria; ${ }^{2}$ Department of Urban and Regional Planning(URP) at the Faculty of the Environmental Sciences at Rivers State University(RSU) Nkpolu, Port Harcourt, PMB 5080, Port Harcourt, Nigeria.

\section{ABSTRACT}

The housing deficit in Nigeria is reportedly of the order of 17 million units. The private sector remains the major supplier as in some other developing countries. However, productivity in Nigeria is hampered by many factors, including high cost of building materials, difficulty in obtaining title to land, a weak mortgage financing sector, and delay in obtaining building permit. In the study area, Greater Port Harcourt City, there is paucity of information on various aspects of housing, including supply, demand, nature of housing provided, satisfaction levels and relationship between housing and stage in the family life cycle. Therefore, the objectives of the research were to: (1) Ascertain the state of private residential housing estate development in GPHC; (2) ascertain the sources of private residential housing and the relative importance of private visà-vis public residential housing delivery; (3) critically examine the number, type and quality of housing provided in private residential estates and their functionality from the point of view of beneficiaries; and (4) ascertain bottlenecks to private residential estate housing delivery. This study was undertaken as a cross-sectional survey of (1) a probability sample of all persons residing in privately built estates and (2) all individuals or corporate firms who have supplied at least 4 building units and above constructed between 1978 and 2014 in Greater Port Harcourt City (GPHC). The research design used was the "passive-observational" method. The number of questionnaires administered to estate residents was 400 while the number administered to estate developers was 76 . The study relied on two sources of information - primary and secondary. Primary sources comprised (a) a largely pre-coded questionnaire, administered face-to-face by trained interviewers, (b) Individual Depth Interviews (IDIs) of key informants, (c) direct observation,
*Correspondence to Author:

$\operatorname{Dr}$ (Mrs). A. Ayotamuno

Institute of Geosciences and Space Technology (IGST) at the Rivers State University (RSU) Nkpolu, Port Harcourt, PMB 5080, Port Harcourt, Nigeria.

How to cite this article:

Augusta Ayotamuno and Obinna Victor Chika. Private Estate Housing Productivity in Greater Port Harcourt, Nigeria. American Journal of Educational Research and Reviews, 2018,3:27.

\section{eScîPub}

eSciPub LLC, Houston, TX USA. Website: http://escipub.com/ 
(c) measurement, and (d) photography. Secondary sources included: (a) unpublished and published material in past theses, books, journals, maps, etc; and (b) the Internet. Data analysis utilised mainly univariate and multivariate statistical analytical techniques. Analysis was carried out with the aid of the microcomputer - adapted Statistical Package for the Social Sciences (SPSS), version 16. The results showed that 1,761 housing units -- mostly in Obio/Akpor LGA (80\%) -- were built by the private sector as opposed to 3,453 units by government. Housing types were singlefamily bungalow (28.3\%), multi-family block of flats (26.8\%), single-family storey building (18.8\%), "wagon" rooming house (4.3\%) and "courtyard" rooming house (1.8\%). Four predictor variables -Access to Land, Mortgage Financing, Building Permit, and Title to Land could explain 85\% of the variation in the dependent variable, Private Housing Productivity, with Title to Land being the most important. The study concluded, among others, that (a) the pace of private sector housing development in Greater Port Harcourt City was far short of what is needed to satisfy demand, given a population of the order of 2,000,000 growing at 5.8\% per annum. Recommendations of the study include (a) Stamp Duty Subsidy such as "instruments, payable on documents such as Lease / Tenancy Agreements, Sale Purchase, Agreements, Transfer and Mortgages. (b)Government should formulate policies and implement techniques that promote liveability in Greater Port Harcourt City. (c) Making land available for estate developers or regulating the price of land can be implemented.

Key Words: Private Housing Estate, Private Developers, Housing Productivity and Land

\section{INTRODUCTION}

Traditionally there have mainly been two sources of housing - public and private. Recently another source has emerged - housing provided through public-private-partnership (PPP). Nevertheless, the private housing sector remains the main source of housing in any environment. The social and economic dynamics in the lifestyle of people and the challenges facing the demand and supply balance have made this study necessary.

Indeed, the pattern of ownership in the United States of America only changed during the 1970s; until then, the vast majority of apartment owners were relatively amateur landlords who owned one, or just a few, small apartment buildings. Many lived in their own apartment buildings, knew the tenants on a first-name basis, and might even peg rent levels to their tenants' ability to pay"(Drakakis-Smith, 1979).

The characteristics of the tenant population depend fundamentally upon the nature of the local housing market. In certain cities one kind of household may own whereas in others the same kind of household may rent. A household's decision rests on the relative costs of renting versus owning and upon the relative size of the rental housing stock. Most households choose 
their tenure only within the range of supply options available (World Bank, 1993). In some places, certain options are unavailable or are available only at unaffordable prices.

The combination of demand and supply factors produces distinctive tenant profiles in different countries. In the United States of America, Varady and Lipman (1994) have identified six renter 'clusters':

i. Families moving up the housing ladder $(17 \%)$;

ii. Lifestyle renters (21\%);

iii. College graduates starting out $(26 \%)$;

iv. Black renters (15\%);

v. Elderly lifestyle renters 10 per cent); and

vi. Struggling blue-collar workers (11 per cent)

In his study Stren (1990) identifies three categories of private tenants: $10 \%$ who decline "to purchase for reasons such as the need to be mobile or because renting is a "conscious choice"; $42 \%$ who are "new entrants to the housing market", who aspire to homeownership; and $48 \%$ who have no choice because their income is too low or too insecure to enter owneroccupation or because they cannot enter the social housing sector (Stren, 1990). In short, while there are similarities between tenant cohorts across cities, there are also important differences.

In some developed countries the poorest households tend to rent, and the richest tend to own. In the United States, despite significant differences in the role of public housing, numerous surveys have demonstrated that incomes of homeowners are on average much higher than those of tenants (Almarza, 1997). In modern Spain, the same pattern is evident because "rental demand is mainly a captive demand, formed by collectives in a precarious labour situation or with not enough income to access ownership" (Bond, 2000).

In the United Kingdom, and increasingly other parts of Europe, many researchers have observed that the housing market has become polarized between those who can afford to own, and those who are too poor to do so (Ha, 1994).
According to Malpezzi (1993) a significant proportion of city dwellers all across the globe, roughly about $40 \%$ of the world's population, lives in some form of rented accommodation.

About $60-80 \%$ of housing across the world has been provided by the private sector (UNHABITAT, 2003). This is increasingly by small investors for their workers as part of their social obligation or for profit. "Currently over $90 \%$ of Nigerians in the low income bracket cannot afford decent accommodation even if they saved $100 \%$ of their income for 10 years" (Awofeso, 2010). Much of the accommodation will have to be provided by the private sector. It has become imperative to investigate the important role private housing plays in the overall housing delivery in Nigeria and particularly in Greater Port Harcourt.

In Greater Port Harcourt currently public and private supply of housing are not based on people's quality of demand, needs and expectations. The demand of the people in certain locations of the city will differ; every properly designed city is zoned into low, medium and high densities to accommodate the various income classes. Unfortunately, government policy hitherto has favoured the middle and high income groups since government sites-andservices housing schemes (layouts) have usually been provided for these higher income groups to the exclusion of the poorest classes. Even when so-called low income housing has been provided by government, units are often allocated to the higher income groups, under such arguments as failure of the poorest groups to provide the required initial down payment and to meet the cost recovery arrangements of government.

Furthermore housing provided by government and by the private sector is hardly ever matched to different stages in the family life cycle, so that rental housing often engenders much dissatisfaction on these grounds.

This research attempts to fill the gap in knowledge regarding number, types and quality of housing provided, bottlenecks to production, 
socio-economic groups served, and satisfaction levels.

There is no government office that stores and manages data on types of private development taking place in Greater Port Harcourt City (GPHC). What has been happening is speculative development, which is not regulated. Anyone who is financially buoyant can buy land and build whatever suits them and not necessarily building to meet a particular need in the society. Private developers are not organized into an association as obtains in developed countries; and therefore they cannot negotiate as a group with government to create an enabling environment to enhance private housing estate productivity. This research hopes to proffer solutions to private estate housing productivity in Greater Port Harcourt.

\section{Goal}

The goal of the study is to ascertain the nature, level and relative importance of private residential housing estate provision in the study area and to address challenges to productivity.

\section{Objectives}

The objectives of the research are to:

(a) To examine the major producers of private residential housing estates in the study area?

(b) To examine what suppliers of private residential housing estate see as the greatest challenges to their productivity?

\section{STUDY AREA- BACKGROUND INFORMATION ABOUT THE STUDY AREA}

The Greater Port Harcourt City Master Plan is a holistic plan for the development of the Greater Port Harcourt City which spans eight (8) Local Government Areas in Rivers State of Nigeria, namely; the whole of Port Harcourt Local Government Area (LGA) and parts of Oyigbo, Okrika, Ogu/Bolo, Obio/Akpor, Ikwerre, Etche ,Eleme LGAs with a population of approximately 2 million people. The Master Plan is for a period of 50 years, it will be reviewed periodically to ensure that it continues to meet with changing realities of an emerging city. The key anchors of the New City are the Port Harcourt International Airport, the Old City and Onne seaport. The http://escipub.com/american-journal-of-educational-research-and-reviews/
Greater Port Harcourt City spans a total landmass of $19,000 \mathrm{~km}^{2}$ (GPHCA, 2009). Figure 1. shows the study area.

\section{METHODOLOGY}

- Research Design;

- Population and Sample;

- Instrumentation and Data Collection; and

- Analytical Techniques.

\section{Research Design}

This study employed the passive-observational category because it did not involve manipulation of the target populations. They were rather studied in situ at one point in time.

\section{Population and Sample}

\section{Elements of Target Population}

The elements of a target population are the units for which information is sought; they are the units of analysis, which have to be defined in terms of (a) content, (b) units, (c) extent and (d) time (Kish, 1965).

\section{Target Populations in this Study}

There are two target populations in this study:

(1). All households (residing in dwelling units) privately-built residential estates, in household units, within the territory of GPHC, with respect to estates built between 1978 and 2014;

(2). All persons, individual or corporate, who are residing within the territory of GPHC that have supplied at least 4 building units or more (in residential estates) between 1978 and 2014.

(3). The objective of sample design in this study was to obtain a representative sample of the target population, so that estimates of the population parameters could be obtained at the level of precision specified. The level of precision (sampling error) is the range within which the true value of the population lies. This range is often expressed in percentage terms. 


\section{Augusta Ayotamuno and Obinna Victor Chika, AJERR, 2018; 3:27}

(4).In this study, a precision level of $5 \%$ was adopted in the sampling of target population. (1)

(5).Probability sampling was used in this study. This type of sampling is defined as one in which "every element of the population has a known and non-zero chance of being selected" (Kish, 1967), as opposed to non-probability sampling where samples are obtained haphazardly, i.e. through the judgment of the researcher.
(6).Sampling frames (as explained in the next paragraphs) were used in this study to ensure probability sampling. A sampling frame is a list or other device used to define a researcher's population of interest. The sampling frame defines a set of elements from which a researcher can select a sample of the target population (Currivan, 2004).

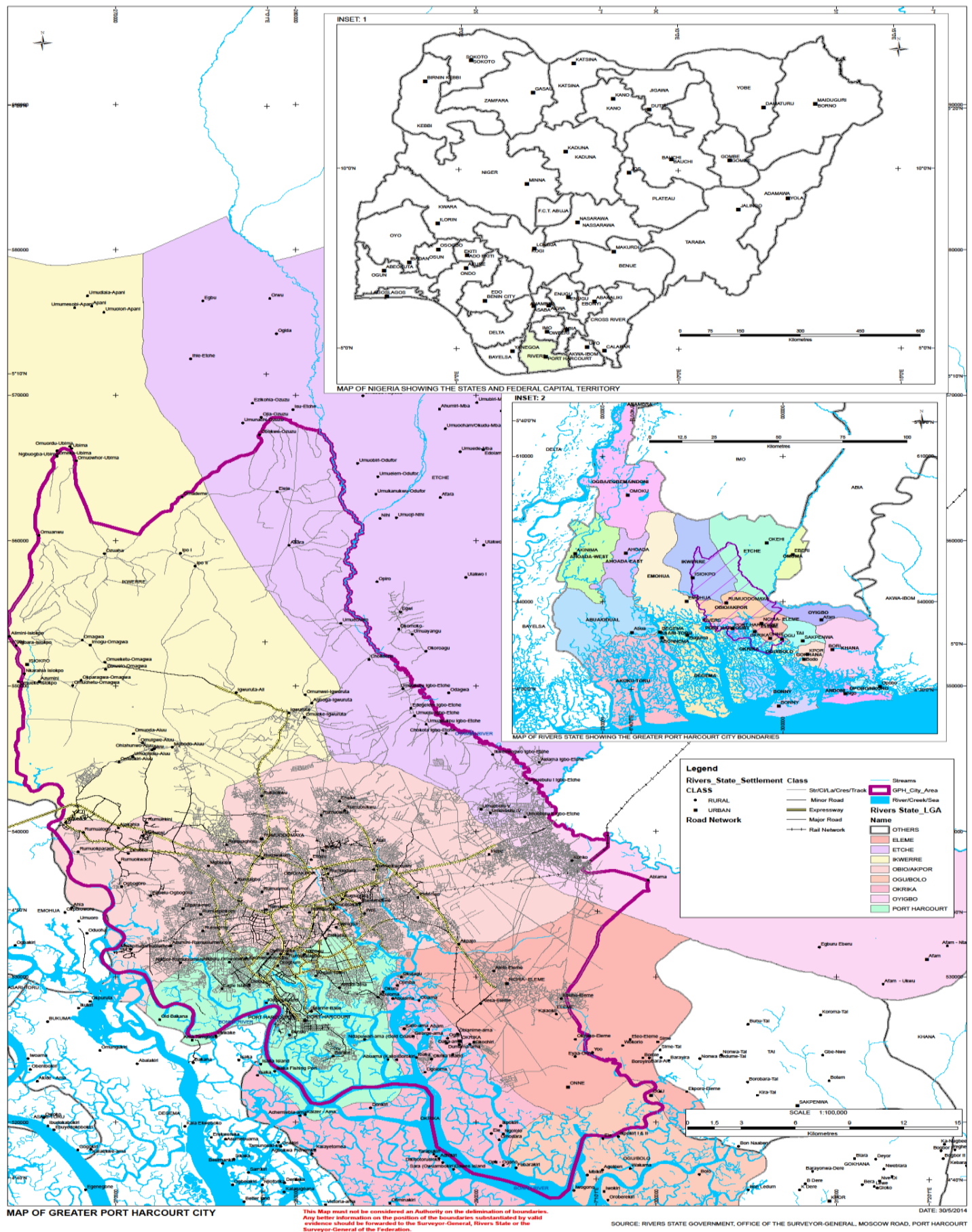

Fig 1:.Map of Greater Port Harcourt Area. Nigeria and Rivers State inset (1 \& 2)

http://escipub.com/american-journal-of-educational-research-and-reviews/ 


\section{Sampling}

\section{Target Population 1 - (Ordered list of housing and dwelling units)}

This comprised an ordered list of 1761 (One thousand, seven hundred and sixty one) housing units comprising dwelling units. A household occupies a dwelling unit. Therefore, a sample of dwelling units also represents a sample of households. There was a total of 2,475 dwelling units (ie, 2,475 households) contained in private residential estate buildings constructed between 1978 and 2014 by private developers throughout the 8 Local Government Areas (LGAs) that wholly or partially fall within the GPHC territory.

Taro Yamane (1967) devised a method for determining the appropriate sample size, when the level of precision is specified.

This is given by the formula

$$
n=\frac{N}{\left(1+N(e)^{2}\right)}
$$

Where, $\mathrm{n}=$ sample size, $\mathrm{N}=$ target population, and $\mathrm{e}=$ level of precision

The Taro Yamane formula was then applied to this number of 2,475 dwelling units or households (at the $5 \%$ level of precision) to yield 344 dwelling units (households):

$$
\begin{aligned}
& n=\frac{N}{\left(1+N(e)^{2}\right)} \\
& n=\frac{2,475}{\left(1+2,475(0.05)^{2}\right)} \\
& n=344.34
\end{aligned}
$$

A round figure of 400 was used in the study to allow for possible non - response, since the figure of 344 was considered a minimum at the specified level of precision $-5 \%$. Thereafter, systematic probability sampling was applied to the ordered list of households/dwelling units to choose the actual households to be questioned. Considering the sample size of 400 and the total household dwelling units of 2,475 , the sample fraction was 1 in 6 . Then after making a random start between 1 and 6 in the ordered list of households/dwelling units, every other $6^{\text {th }}$ case was picked, until the end of the list was reached, yielding the desired sample size of 400 . Therefore it was straightforward to determine the actual households to be questioned, since in the ordered list, every household/dwelling unit was attached to a particular building in a particular estate. The head of each household was the respondent to each questionnaire as he/she was considered the most knowledgeable about household conditions.

\section{Target Population 2 - Private Developers}

The total number of relevant private developers was 100 (ascertained from field research). Since this number was relatively small, no sampling took place. Rather the research adopted a census of these developers. Of the 100 developers, 76 (seventy-six) responded. Therefore the analysis of responses was based on this number.

\section{Instrumentation and Data Collection}

Data for this study were collected from both primary and secondary sources.

\section{Primary sources comprised:}

i. A largely pre-coded questionnaire, which was administered face-to-face by trained interviewers to a probability sample of households residing in privately built residential estates;

ii. Individual Depth Interviews (IDIs) of key informants (persons knowledgeable in public and private housing delivery)

iii. Direct observation and measurement of housing aspects; and

iv. Photography of housing features.

\section{Secondary sources comprised:}

Official documents which were gotten from Ministries, Departments and Agencies (MDA) include the following;

(a) Greater Port Harcourt City Development Authority - Policy Documents

(b) Rivers State Ministries of Lands and Survey (Maps), Urban Development and Physical Planning (Building Permit 


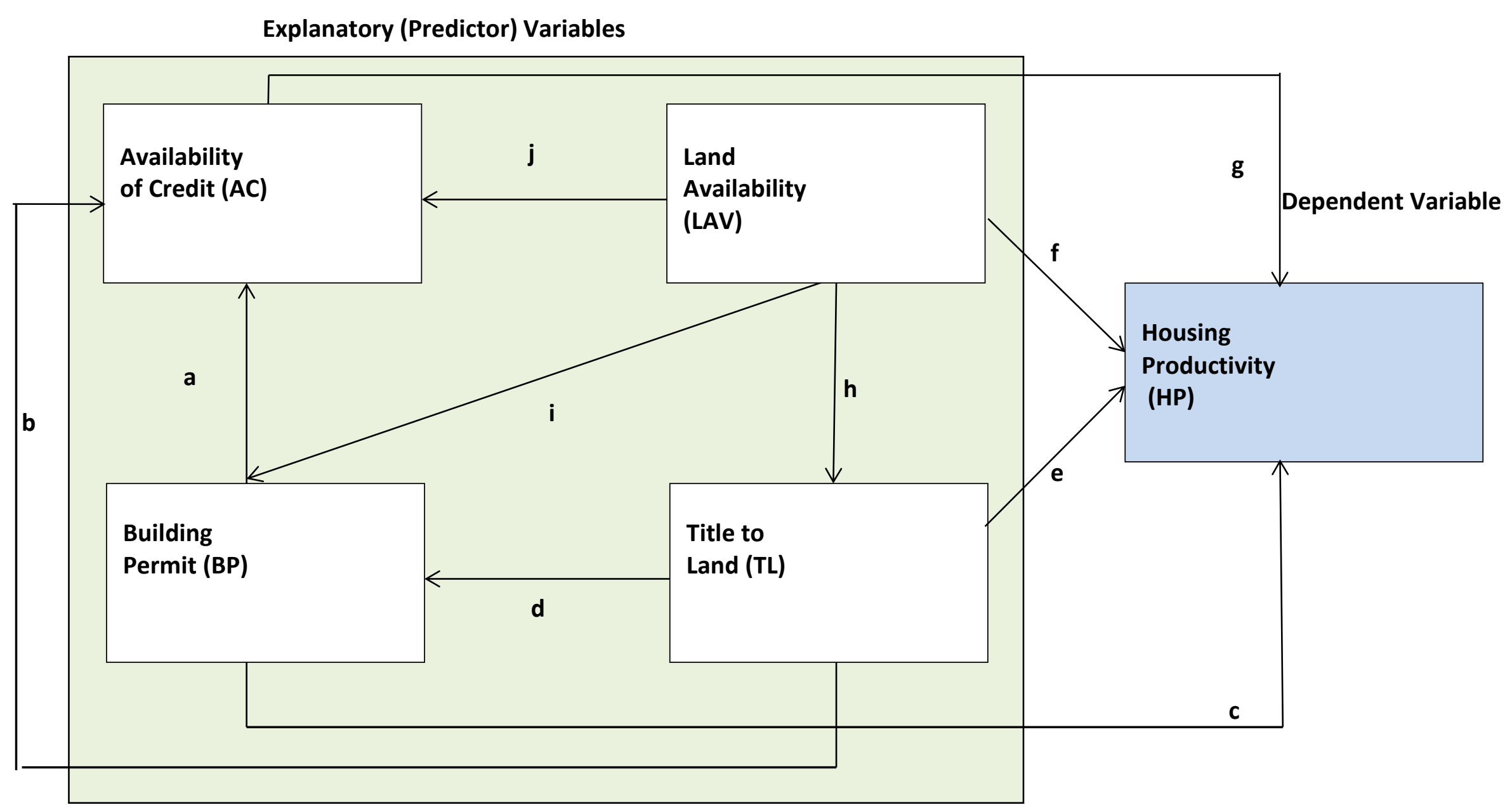

Figure 2:.Conceptual Model of the Study. The arrows (a) to (j) point in the "causal" directions. 

(a) Approval list), Rivers State Ministries of Housing (List of Estate buildings built)

\section{Analytical Techniques}

\section{Conceptual Model of the Study}

(b) Rivers State Geographic Information System (RIVGIS) - Registration Timeline Schedule

(c) Federal Mortgage Bank of Nigeria (FMBN) - List of Contributors and Contribution

(d) Primary Mortgage Institutions (PMls) Guidelines of Operation

(e) National Population Commission (NPC) - Population Figures

(f) National Bureau of Statistics Documents on Demography

The number of questionnaires administered to estate residents and estate developers were 400 and 76 respectively.
Figure 2 shows the conceptual model of the study. It was posited that the following variables: (a) Title to Land (Certificate of Occupancy);(b) Availability of Credit; (c) Land Availability and (d) Building Permit could explain variation in housing productivity among private developers.

\section{Hypothesis}

The null hypothesis is that:

There is no significant relationship between land availability, availability of credit, building permit, title to land and housing productivity (arrows (f), (g), (c), and (e), respectively) as shown in Figure $2(\alpha=0.05)$.

\section{Operational Definitions of Concepts}

\section{Table 1:.Operational Definition of Study Concepts}

\begin{tabular}{|c|c|c|}
\hline S/No. & Concept & Operational Definition \\
\hline 1 & Title to Land & $\begin{array}{l}\text { Reported length of time (in months) to obtain title (Certificate of } \\
\text { Occupancy) }\end{array}$ \\
\hline 2 & Availability of Credit & $\begin{array}{l}\text { Reported ease/difficulty in obtaining credit to build from Primary Mortgage } \\
\text { Institutions }\end{array}$ \\
\hline 3 & Land Availability & Reported ease/difficulty in obtaining land to build \\
\hline 4 & Building Permit & $\begin{array}{l}\text { Reported length of time (in months) to obtain building permit from the } \\
\text { Ministry of Urban Development }\end{array}$ \\
\hline 5 & Housing Productivity & Number of housing units produced by private developers \\
\hline
\end{tabular}

(Source: Author's Field Survey, November 2014)

\section{Data Preparation for Analysis \\ Data Screening and Error Correction}

Prior to the computer analysis (with the aid of the micro-computer-adapted Statistical Package for the Social Sciences (SPSS), Version 16), the data set was checked for errors. The latter included scores that were out of range (i.e. not within the range of possible scores).Such errors were located in the data files and corrected after reverting to the original responses in the field data gathering instruments. Computer- generated variable frequencies were used to double-check, to ensure that all "wild codes" had disappeared.

\section{Statistical Analytical Techniques}

\section{Univariate Analysis}

This entailed the use of such univariate summary statistics as the mean, median, mode, standard deviation, variance, range, skewness and kurtosis. Frequency distribution for all the variables were obtained and used initially to check data accuracy. 


\section{Multivariate Analysis}

For multivariate analysis, the study employed the Multiple Classification Analysis (MCA) technique (Andrews, et al., 1976). This is a special type of regression technique that was used to explain variance in the dependent variable, using independent or predictor variables. This technique requires that the dependent variable be measured on the interval (continuous) scale or be dichotomous, while the independent variables could be nominal/categorical, ordinal, continuous, or ratio.

The MCA technique is given by the equation:

$Y_{i j \ldots . . . n}=\hat{Y}+a_{i}+b_{j}+\ldots+e_{i j \ldots . . .}$

$Y_{i j . . . n}=$ The score (on the dependent variable (i.e. Housing Productivity (HP)) of individual who falls in category $i$ of predictor $A$ $(A C)$, category $j$ of predictor $B(L A V)$, etc.

$\hat{Y} \quad=$ Grand mean of the dependent variable (HP)

$\mathrm{a}_{\mathrm{i}}=$ The "effect" of membership in the $\mathrm{i}^{\text {th }}$ category of predictor $A(A C)$.

$b_{j}=$ The "effect of membership in the $j^{\text {th }}$ category of predictor B

$\mathrm{e}_{\mathrm{ij} . \ldots \mathrm{n}}=$ Error term for this individual

The Multiple Classification Analysis technique yields three key coefficients such as: Eta ( $\eta$ ), Beta $(\beta)$ and multiple $R$ squared

(a) Eta and Eta2indicates the ability of the predictor, using the categories given, to explain variation in the dependent variable $E \mathrm{ta}^{2}$ is the correlation ratio and indicates the proportion of the total sum of squares explainable by the predictor.

(b) Beta and Beta2: these are directly analogous to the eta statistics, but are based on the adjusted means rather than the raw means. Beta provides a measure of the ability of the predictor to explain variation in the dependent variable after adjusting for effects of all other predictors. (c) A multiple correlation coefficient squared (adjusted for degrees of freedom). This coefficient estimates the proportion of variance in the dependent variable explained by all predictors together.

MCA was used in this study to examine how, taken together, the predictor (independent) variables (Title to Land (Certificate of Occupancy), Availability of Credit, Land Availability and Building Permit) explain variation in the dependent variable (Housing Productivity) as well as the relationship between each of the aforementioned independent variables and the dependent variable while holding constant the effects of other predictors. In addition to a multiple $R^{2}$, the statistics include an eta coefficient indicating how each independent variable is related to the dependent variable and a beta coefficient for each independent variable indicating its relative importance in the total variance explained.

\section{Hypothesis Testing}

In order to test the null hypothesis of no linear relationship between the predictor variables and the dependent variable, the One - Way Analysis of Variance (ANOVA) (Blalock, 1979) was used. Fortunately, this is one of the options available in the MCA technique, since specifying only one predictor in the MCA programme is tantamount to running a One - Way ANOVA (Andrews, et al, 1976).

\section{FINDINGS AND DISCUSSION}

\section{Sources and Importance of Private Housing Development in Greater Port Harcourt City}

The major sources of housing estates in Greater Port Harcourt City (GPHC) from the research are the private and public sectors. The private sector is further divided into individual developers and corporate firms. In order to have a better understanding of the level of provision of housing estates in GPHC between 1978 2014 the number of estates built by the private 


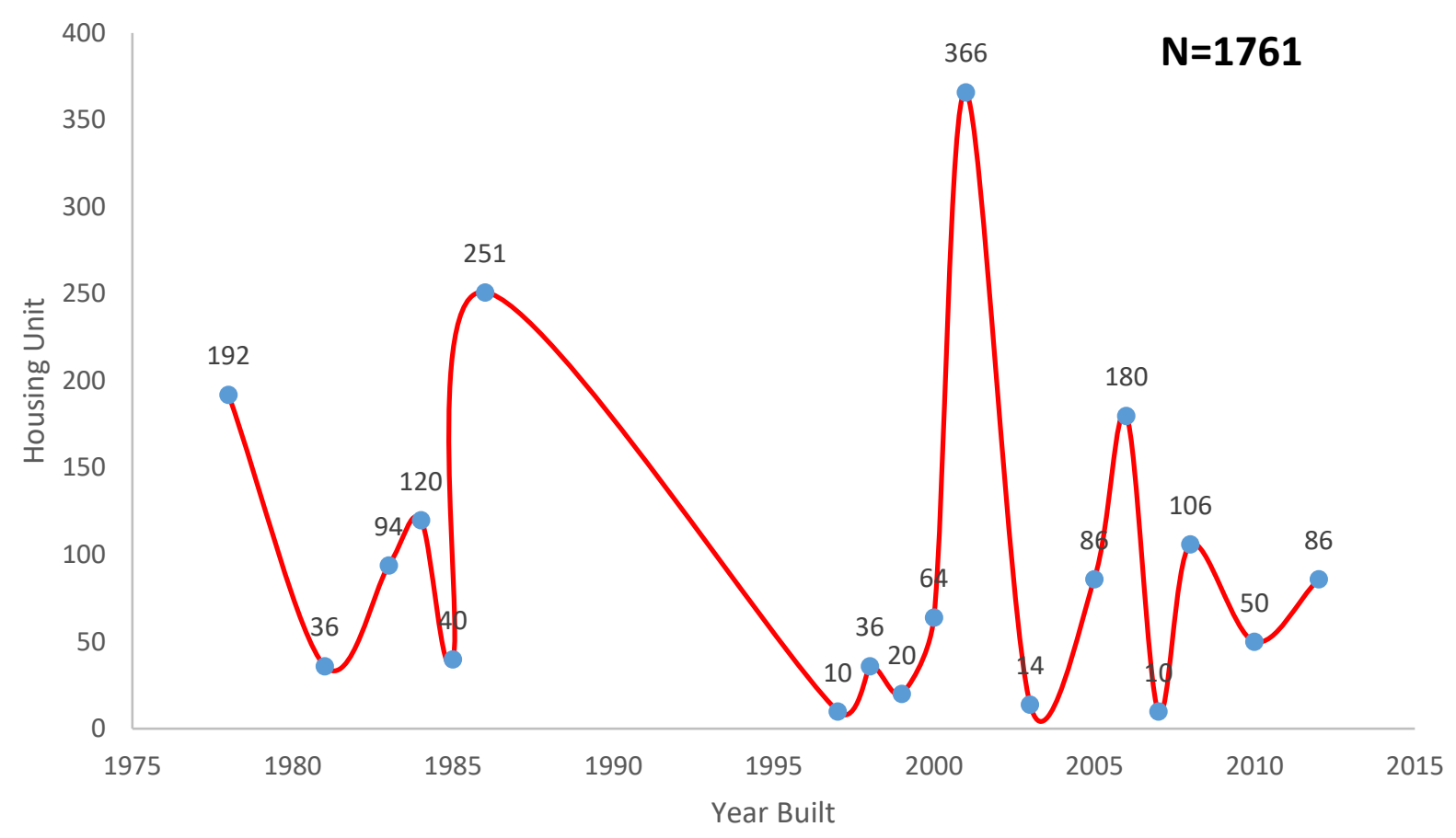

Figure 3:.Units of Housing Built by Private Sector Estate Developers in GPHC Between 1978 and 2014 (Source: Author's Field Survey, November 2014)

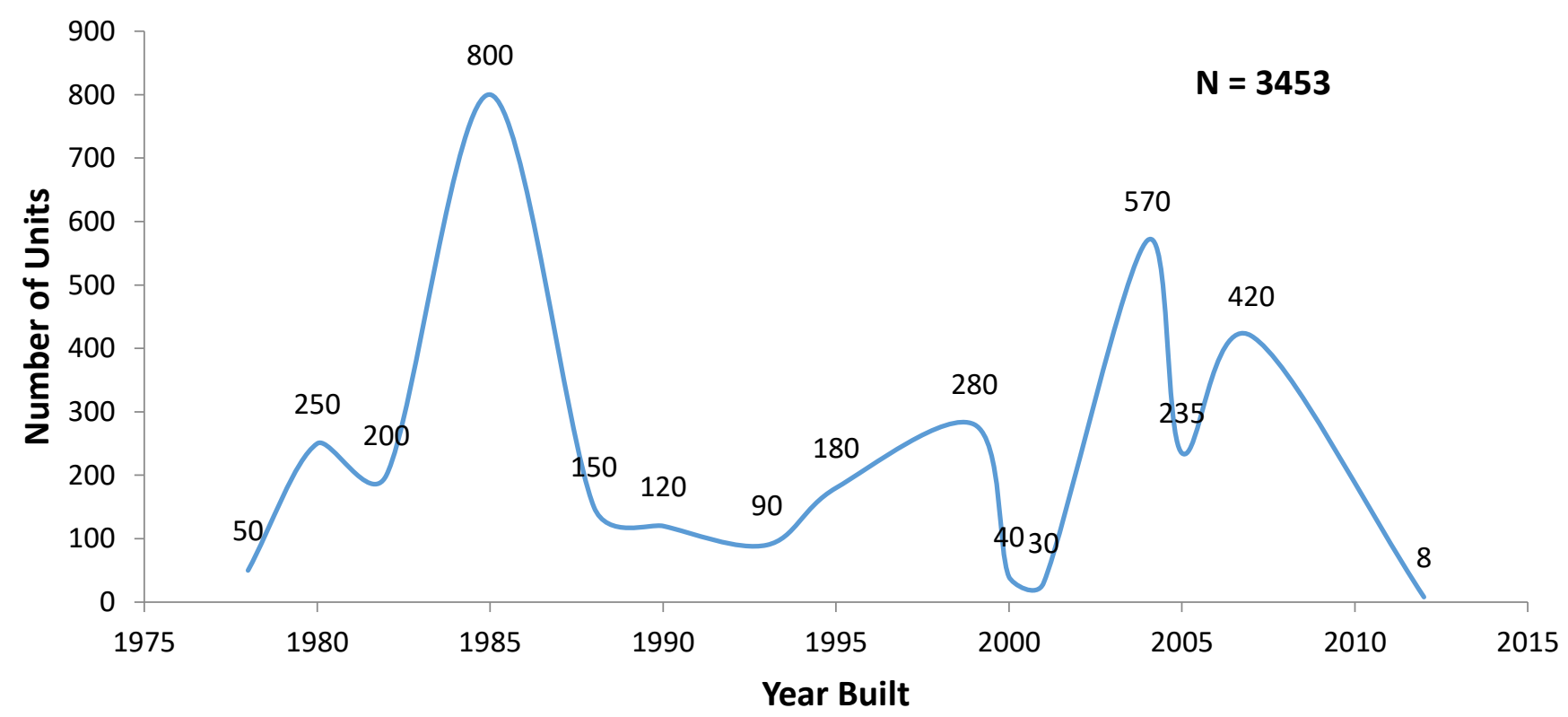

Figure 4: Units of Housing Built by Government in GPHC between 1978 and 2014 (Source: Author's Field Survey, November 2014)

sector is compared with that provided by the public sector as shown in figures 3 and 4 .

Government has provided 3,453 housing units while the private sector has provided only 1761 , totalling 5,214 units. Of this number, the private and public sectors have therefore provided $33.77 \%$ and $66.33 \%$, respectively. This relatively low level of provision of housing estates by the private sector helps to account for the paucity of decent rental accommodation in GPHC. This is 
in sharp contrast with what is known in the literature that all over the world, including Nigeria, the private sector is the major provider of rental housing.

Salau (1992) has reported that the informal private sector supplies a large percentage of rental housing in Nigeria, providing accommodation for the majority of city dwellers. Public housing accounts for only $10 \%$, compared to nations like Singapore where public housing provision is put at $90 \%$. The situation in GPHC appears to follow the Singapore trend of public sector dominance, although, clearly, the private sector needs to be strengthened.

It is evident that government has produced more housing units from a single estate -- 699 housing units -- than the private sector, where the corresponding figure is 433 . From this research, public average annual supply of housing units over the study period stood at 102 units as against 22 units by the private sector. This pace of private sector housing development in GPHC is far short of what is needed to satisfy demand, given a population of the order of $2,000,000$, supposedly growing at the rate of $5.8 \%$-- the average urban annual growth rate reported by the National Urban Development Policy document (2006).

The level of production of housing in a developing country like Nigeria is only 2 dwelling units per thousand people (Anthonio, 2002), compared to the required rate of about 8-10 dwelling units per 1,000 population as recommended by the United Nations (Anthonio, 2002). For instance, in the almost 40 years of creating the Federal Housing Authority (FHA), it has only succeeded in building about 40,000 housing units nationwide (Adediji, 2009), which translates to 1,000 units per annum.

The current population of GPHC is about $2,000,000$. Given the recommendation of the UN, the ideal production rate of housing should be about 167 units annually, which is inclusive of all types of private housing. This particular research only focused on privately built housing estates that had 4 units and more. Results showed that 22 units were built annually. Although this does not give the total picture of privately built housing in GPHC, this level of provision is still a far cry from the UN recommendation.

In terms of quantity the public sector has provided more than the private sector and quantity is what is required in providing mass housing for any city. Mass housing refers to housing provided by public authorities and private corporations on a large scale at highly subsidised rental and sales rates for the benefit of society (Jiboye, 2009) while affordable housing is income-determined housing that accounts for one-third to one-quarter of the monthly take home pay of the middle class and the poor (Jiboye, 2009).

\section{Estimating Relationships in the Conceptual Model}

\section{Relationship between Predictors and the Dependent Variable}

The study hypothesized that there are linear relationships between the 4 predictor variables (Experience in Obtaining Land, Difficulty in Getting Loans, Length of Time to Obtain Building Permit and Length of Time to Obtain Certificate of Occupancy) and the dependent variable (Housing Productivity) at the 0.01 alpha levels. Therefore, there were tests of the null hypotheses of no significant linear relationships between each of the predictors and the dependent variable.

The correlation coefficient used by MCA was eta (which is analogous to Pearson $r$ or the product moment correlation coefficient) (Andrews, et. al., 1976). The one-way Analysis of Variance (ANOVA) technique can be used for the hypothesis testing (Blalock, 1979). Fortunately, MCA has the option of running ANOVA when only when predictor is specified (Andrew, et. al., 1976). This option computes the $F$ value (the test statistic), showing the degrees of freedom. The appropriate decision rule is to reject the null hypothesis if $F$ is greater than $C$ (critical value derived by examining the $\mathrm{F}$ Statistical Table, 
specifying the degrees of freedom and the relevant significance level).

Computer results of the MCA-ANOVA tests for each of the predictors and the dependent variable.

\section{Using the Predictors to Explain Variation in Housing Productivity}

In order to use the predictors (independent variables) to explain variation in the dependent variable, Housing Productivity, Multiple Classification Analysis was used. Beta scores revealed the order of importance of the predictors in explaining variation in the dependent variable. Figures in parentheses in the last column of Table 3 show this order. Thus, the most potent predictor variable was Length of Time to Obtain Certificate of Occupancy, followed by Experience in Obtaining Land, Length of Time to Obtain Building Permit, and Difficulty in Getting Loans, in that order. Adjusted eta is the bivariate correlation coefficient (i.e. between the predictor and the dependent variable), while the adjusted eta square coefficient shows the amount of variance in the dependent variable explained by the predictor (see Andrews et al, 1976). Taken together, all the predictors could explain $85 \%$ of the variation in the dependent variable, Housing Productivity.

Table 2: Testing Hypothesis of no Linear Relationship between the Predictors and the Dependent Variable

\begin{tabular}{|c|c|c|c|c|c|c|}
\hline S/No & $\begin{array}{l}\text { Null Hypothesis } \\
\left(\mathrm{H}_{0}\right)\end{array}$ & $\begin{array}{l}\text { Eta Squared } \\
\text { (Unadjusted) } \\
\text { (\% variance } \\
\text { explained) }\end{array}$ & $\begin{array}{l}\text { Compute } \\
\text { d F Value }\end{array}$ & $\begin{array}{l}\text { Critical Value } \\
\text { (0.01significa } \\
\text { nce) }\end{array}$ & Decision Rule & $\begin{array}{l}\text { Decision } \\
\text { Taken }\end{array}$ \\
\hline 1. & $\begin{array}{l}\text { There is no linear } \\
\text { relationship between } \\
\text { Experience in } \\
\text { Obtaining Land and } \\
\text { Housing Productivity }\end{array}$ & 0.16 & 4.57 & $\begin{array}{l}F(3,72) \\
4.13\end{array}$ & $\begin{array}{l}\text { Reject } \mathrm{H}_{0} \text { if } \\
\text { computed } \mathrm{F} \text { value } \\
\text { is greater than } \\
\text { tabulated value } \\
\text { (Critical value) }\end{array}$ & $\begin{array}{l}\text { Reject null } \\
\text { hypothesis. }\end{array}$ \\
\hline 2. & $\begin{array}{l}\text { There is no linear } \\
\text { relationship between } \\
\text { Difficulty in } \\
\text { Obtaining Loans and } \\
\text { Housing Productivity }\end{array}$ & 0.15 & 4.35 & $\begin{array}{l}4.13 \\
F(3,72)\end{array}$ & $\begin{array}{l}\text { Reject } \mathrm{H}_{0} \text { if } \\
\text { computed } \mathrm{F} \text { value } \\
\text { is greater than } \\
\text { tabulated value } \\
\text { (Critical value) }\end{array}$ & $\begin{array}{l}\text { Reject null } \\
\text { hypothesis }\end{array}$ \\
\hline 3. & $\begin{array}{l}\text { There is no linear } \\
\text { relationship between } \\
\text { length of Time to } \\
\text { Obtain Certificate of } \\
\text { Occupancy ( } C \text { of } O) \\
\text { and Housing } \\
\text { Productivity }\end{array}$ & 0.61 & 30.3 & $\begin{array}{l}3.56 \\
F(4,71)\end{array}$ & $\begin{array}{l}\text { Reject } \mathrm{H}_{0} \text { if } \\
\text { computed } \mathrm{F} \text { value } \\
\text { is greater than } \\
\text { tabulated value } \\
\text { (Critical value) }\end{array}$ & $\begin{array}{l}\text { Reject null } \\
\text { hypothesis }\end{array}$ \\
\hline 4. & $\begin{array}{l}\text { There is no linear } \\
\text { relationship between } \\
\text { Length of time to } \\
\text { Obtain Building } \\
\text { Permit and Housing } \\
\text { Productivity }\end{array}$ & 0.23 & 4.28 & $\begin{array}{l}3.31 \\
F(5,70)\end{array}$ & $\begin{array}{l}\text { Reject } \mathrm{H}_{0} \text { if } \\
\text { computed } \mathrm{F} \text { value } \\
\text { is greater than } \\
\text { tabulated value } \\
\text { (Critical value) }\end{array}$ & $\begin{array}{l}\text { Reject null } \\
\text { hypothesis }\end{array}$ \\
\hline
\end{tabular}

(Source: Author's Field Survey, November 2014) 
Table 3: Explaining Variation in Housing Productivity (Multiple Classification Analysis, $\mathrm{N}=76$ )

\begin{tabular}{|c|c|c|c|}
\hline \multirow{3}{*}{$\frac{\text { Variables }}{\text { Experience in Obtaining Land }}$} & \multicolumn{3}{|l|}{ Coefficients } \\
\hline & Adjusted Eta & \multirow{2}{*}{$\begin{array}{c}\text { Adjusted Eta } \\
0.13\end{array}$} & Beta \\
\hline & 0.35 & & 0.58 \\
\hline Difficulty in Getting Loans & 0.34 & 0.12 & $0.36 \quad(4)$ \\
\hline Length of Time to Obtain Building Permit & 0.42 & 0.18 & $0.52(3)$ \\
\hline $\begin{array}{l}\text { Length of Time to Obtain Certificate of } \\
\text { Occupancy }\end{array}$ & 0.78 & 0.61 & $0.77(1)$ \\
\hline \multicolumn{4}{|l|}{ Adjusted Multiple $\mathrm{R}^{2}$} \\
\hline (Explained Variance) & 0.85 & & \\
\hline
\end{tabular}

* The numbers in parentheses indicate the order of importance of the predictors in explaining variation in the dependent variable (Housing Productivity). (Source: Author's Field Survey, November 2014)

\section{CONCLUSIONS AND RECOMMENDATIONS Conclusions}

At the end of the research the following conclusions were made about private housing development in Greater Port Harcourt City (GPHC).

First, the pace of private sector housing development was found to be far short of what is needed to satisfy the demand, given a population of the order of 2,000,000 supposed to be growing at $5.8 \%$ per annum (the average urban annual growth rate as determined by the National Population Commission). Private developers surveyed were apparently not concerned with providing housing to meet the needs of all strata in the society, but have hitherto concentrated on the medium and high income groups.

\section{Recommendations}

(1) Stamp Duty Subsidy: Stamp duty is a tax on legal documents which are called "instruments, payable on documents such as Lease / Tenancy Agreements, Sale Purchase, Agreements, Transfer and Mortgages. This will encourage estate developers and investors to produce mass housing. This will aid investment and incentives for private housing development.

(2) Government should formulate policies and implement techniques that promote liveability in Greater Port Harcourt City. This can be achieved during the approval of building plan and building permit .processes by monitoring the project from start to finish.

(3) Government should provide an enabling environment for estate developers and to encourage investors. Making land available for estate developers or regulating the price of land can be implemented.

\section{REFERENCES}

1. Adediji, B. (2009). International Housing Finance and World Economic Meltdown vis-vis Nigeria's Housing Delivery System. A paper presented at MCPD Workshop organized by the Akwa lbom State Branch of the Nigerian Institution of Estate Surveyors and Valuers, Uyo.

2. Almarza, S., (1997). "Financiamento de la vivienda de estratos de ingresosmediosbajos:Laexperienciachilena",

CEPAL SerieFinancimientodelDesarrollo, 46, Santiago.

3. Andrews, F. M., Morgan, J; Sonquist, J \& Klem, Laura (1976). Multiple Classification Analysis. 
Ann Arbor (USA). The University of Michigan, Institute for Social Research, 105

4. Anthonio, J. B. (2002). Housing for all by the year 2015. Paper presented at the 2002 Building week seminar. Obafemi Awolowo University, lleIfe, Nigeria.

5. Awofeso, P. (2010). One out of two Nigerians now Lives in a City: There are Many Problems but One Solution. World Policy Journal 27, 67.

6. Blalock, H.M., Jr. (1979). Measurement and conceptualization problems: The major obstacle to integrating theory and research, American Sociological Review, 44, 881-894.

7. Bond, P. (2000). Elite transitions: From apartheid to neo-liberalism in South Africa, Pluto Press. South Africa.

8. Cook, T. D. \& Campbell, D. T. (1979). QuasiExperimentation - Design and Analysis Issues for Field Settings. Boston: Houghton Mifflin Company.

9. Currivan, D. (2004) .Sampling Frame in LewisBeck, Michael S. Bryman, Alan, Liao \& Tim F. The Sage Encyclopedia of Social Science Research Methods. SAGE Publications, Inc.Retrieved:http://knowledge.sage pub.com/view/socialscience/ SAGE.xml. Accessed (August 19, 2014).

10. Drakakis-Smith, D.W., (1979), High society: Housing provision in Metropolitan Hong Kong1954 to 1979, Centre of Asian Studies, University of Hong Kong.

11. Greater Port Harcourt City Development Authority (2009). http/www.GPHCDA/ (Accessed) on: September 29, 2013).

12. Ha, S.-K., (1994), "Low-income housing policies in the Republic of Korea", Cities, 11, 107-114.

13. Jiboye, A. D., (2009). Evaluating tenants satisfaction with public housing in Lagos, Nigeria, Town Planning and Architecture, 33(4), 239-247

14. Kish, L. (1965). Survey Sampling: New York: John Wiley and Sons.

15. Malpezzi, S., (1993). Can New York and Los Angeles Learn From Kumasi and Bangalore? Costs and Benefits of Rent Controls in Developing Countries. Housing Policy Debate, 4(4), 589-626.

16. Salau, A. T. (1992). Urbanisation, housing and social services in Nigeria: The challenge of meeting basic needs. In Porter R. B. and Salau A. T. (eds) Cities and development in the Third World. Magnet Publishers, England.

17. Stren, R.E., (1990). "Urban housing in Africa: The changing role of government policy". In Amis, P. and Lloyd, P. (eds.), Housing Africa's Urban Poor, Manchester University Press.

18. United Nations Human Settlements Programme (UNHSP), (2003). Rental Housing An essential option for the urban poor in developing countries Nairobi

19. Varady, D. P. and Lipman, B.J. (1994). "What Are Renters Really Like? Results from a National Survey." Housing Policy Debate. 5 (4 ) 491-531

20. World Bank, (1993). Housing: Enabling markets to work. A World Bank Policy Paper
21. Yamane, T, (1967). Statistics: An Introductory Analysis. Second Ed. New York: Harper \& Row

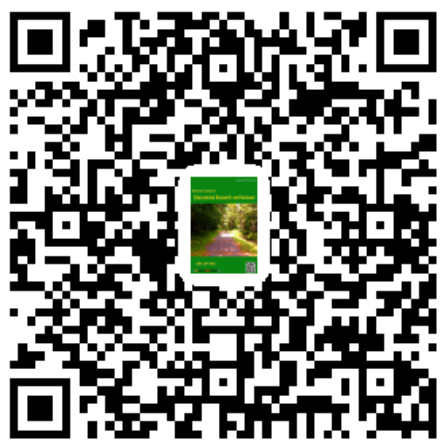

